\title{
Dampak Utang Jangka Panjang atas Pendapatan Entitas Bisnis (Studi Kasus pada Perusahaan Terdaftar di Bursa Efek Indonesia)
}

\author{
Oleh \\ Winston Pontoh
}

\begin{abstract}
ABSTRAK
Aset tetap merupakan hasil dari salah satu kegiatan investasi dalam sebuah entitas bisnis, yang dipertimbangkan tingkat pengembaliannya dalam sebuah periode tertentu. Seringkali sebuah entitas bisnis memperoleh aset tetap tersebut dengan menyertakan unsur pendanaan dari pihak eksternal yang bersifat jangka panjang. Sumber data dalam penelitian ini adalah Bursa Efek Indonesia, dengan sampel sebanyak 253 perusahaan dan metode analisis yang digunakan dalam penelitian ini adalah metode analisis jalur. Hasil penelitian menunjukkan bahwa utang jangka panjang memiliki dampak atas tingkat penjualan, melalui pemanfaatan aset tetap secara optimal.
\end{abstract}

Kata Kunci : Utang Jangka Panjang, Aset Tetap, Pendapatan

\section{ABSTRACT}

Fixed assets are the results of one investment in a business entity, which is considered the level of returns in a given period. Often a business entity acquiring the asset by including an element of funding from external parties who are long-term. Sources of data in this study is the Indonesia Stock Exchange, with a sample of 253 companies and the methods of analysis used in this study is the method of path analysis. The results showed that longterm debt has an impact on the level of sales, through optimal utilization of fixed assets.

Key Word : Long-Term Debt, Fixed Assets, Revenue 


\section{Latar Belakang Masalah.}

Memperoleh laba adalah merupakan tujuan dari sebuah entitas bisnis, guna kesejahteraan pihak-pihak yang terlibat dalam entitas bisnis tersebut. Untuk memperoleh laba yang optimum, maka secara keseluruhan, pendapatan adalah merupakan faktor awal yang utama guna menciptakan laba tersebut. Guna memperoleh tingkat penjualan tertentu dalam rangka untuk memperoleh tingkat laba tertentu, maka optimalisasi pengelolaan aset, khususnya aset tetap guna mendukung proses pemerolehan pendapatan, adalah merupakan kegiatan yang sangat penting bagi pihak manajemen. Hal ini disebabkan karena, aset tetap merupakan alat untuk mendukung proses produksi dalam penciptaan produk yang kemudian akan dipasarkan pada konsumen.

Aset tetap merupakan hasil dari salah satu kegiatan investasi dalam sebuah entitas bisnis, yang dipertimbangkan tingkat pengembaliannya dalam sebuah periode tertentu. Oleh sebab itu, keputusan investasi dalam sebuah aset tetap, harus dipertimbangkan secara matang oleh pihak manajemen, terkait dengan, perolehan sebuah aset tetap akan terkait dengan penggunaan modal sendiri dari entitas bisnis tersebut. Sehingga apabila pihak manajemen tidak memperhitungkan secara matang, maka kegiatan investasi atas aset tetap tersebut akan mendatangkan permasalahan dalam keuangan entitas.

Permasalahan yang muncul adalah, seringkali sebuah entitas bisnis memperoleh aset tetap tersebut dengan menyertakan unsur pendanaan dari pihak eksternal atau disebut utang, yang sering bersifat jangka panjang. Sehingga, hal ini menyebabkan pihak manajemen untuk mempertimbangkan kembali keputusan investasi atas aset tetap, karena akan terkait dengan pengembalian modal sendiri, pembayaran pokok utang dan pembayaran beban bunga utang dalam jangka waktu yang cukup lama. Dan hal ini berarti pihak manajemen akan mengharapkan kenaikan pendapatan atas pemberdayaan atas utang jangka panjang ini lewat aset tetap yang diperolehnya.

\section{Tinjauan Pustaka.}

Chinaemerem \& Anthony (2012), menyatakan bahwa struktur modal dari sebuah perusahaan adalah merupakan faktor penting dalam menentukan kinerja keuangannya. Implikasi atas penelitian mereka menunjukkan bahwa sampel perusahaan yang diteliti, tidak memiliki kemampuan dalam memanfaatkan aset tetap mereka secara optimal sehingga berdampak secara positif terhadap kinerja perusahaan tersebut. Pendapat yang saa dikemukakan oleh Mohamad \& Abdullah (2012). Shubita \& Alsawalhah (2012), menyatakan bahwa keputusan atas struktur modal adalah sangat krusial bagi setiap organisasi bisnis. Keputusan ini sangat penting karena kebutuhan untuk memaksimisasi pengembalian dari berbagai konstitusi organisasional, dan juga disebabkan oleh dampak keputusan organisasi atas kemampuannya untuk menanggapi lingkungan persaingan. Lebih lanjut, dalam penelitian mereka, ditemukan bahwa, terdapat hubungan negatif antara utang dan profitabiliti, akan tetapi profitabiliti mengalami peningkatan dengan adanya variabel ukuran perusahaan dan penjualan.

Mahmud (2003), dalam hasil penelitiannya, menyatakan bahwa, dengan adanya peningkatan penjualan, dan seiring pula dengan peningkatan profitabilitas, maka hal ini selain adanya penggunaan dana internal juga akan berdampak pada kebutuhan penggunaan dana eksternal. Akan tetapi, kemungkinan yang terjadi adalah adanya penggunaan dana internal yang lebih banyak untuk mengabaikan pembiayaan eksternal, dan keadaan ini lebih banyak terjadi di industri-industri Jepang yang telah mapan akan tetapi memiliki pertumbuhan yang kecil atau bahkan tidak sama sekali.

Sadeghian, et. al. (2012), berpendapat bahwa, jika perusahaan memperoleh asetnya berdasarkan utang yang diperoleh, tanpa memperhatikan ukurannya, maka hal ini akan berdampak pada kurang meningkatnya kinerja perusahaan tersebut. Khrawish \& 
Khraiwesh (2010), dalam hasil penelitiannya, menemukan bahwa perusahaan-perusahaan yang berada di Jordania kebanyakan menggunakan utang jangka panjang dalam pembiayaan investasi asetnya, dan hal ini didukung oleh pendapat Alkhatib (2012), Iannariello, Morsy, Hagiwara (2007), Hovakimian, Hovakimian, \& Tehranian (2004), yang mengemukakan bahwa utang merupakan sumber daya yang dipakai oleh perusahaan dalam menjalankan bisnisnya. San \& Heng (2011), menemukan bahwa terdapat hubungan antara struktur modal sebuah perusahaan dengan kinerja dari perusahaan tersebut. Hasil penelitian ini juga didukung oleh Aivazian, Ge, \& Qiu (2005), akan tetapi harus memperhatikan risiko atas investasi tersebut (Chang et. al., 2013). Chhapra \& Asim (2012), menemukan bahwa aset tetap, ukuran perusahaan, laba bersih dan pajak adalah merupakan faktor-faktor penentu dari struktur modal dalam sektor industri di Pakistan.

Adebayo (2013), berpendapat bahwa, produksi merupakan fungsi dari penjualan. Oleh sebab itu, penentuan produk yang akan dihasilkan harus ditentukan oleh pihak pemasaran yang secara efektif akan menyampaikan produk tersebut. Modal yang tetap akan sangat dibutuhkan bagi pihak manufaktur untuk memproduksi produk dalam skala tertentu, dan pada umumnya, perusahaan akan berproduksi dalam jumlah yang besar, sehingga membutuhkan investasi yang besar dalam aset tetapnya. Lebih lanjut, keberhasilan setiap perusahaan akan sangat tergantung dari bagaimana perusahaan mengelola dan meningkatkan asetnya, sehingga akan menyebabkan terjadinya peningkatan penjualan dan laba yang akan menutupi segala ketidakefisienan. Dengan mengevaluasi beberapa hubungan antara penjualan dan aset, maka bagaimana pemanfaatan aset adalah salah satu gambaran bagaimana perusahaan dikelola untuk mengantisipasi keterbatasan sumber daya dan peranannya dalam operasional. Pendapat yang sama juga dikemukakan oleh Okwo, Ugwunta \& Nweze (2012).

\section{Metode Penelitian.}

\subsection{Jenis dan Sumber Data.}

Sumber data dalam penelitian ini adalah Bursa Efek Indonesia untuk periode 2009 sampai dengan 2011, dimana 253 perusahaan dipilih sebagai sampel penelitian. Adapun perincian sampel penelitian adalah sebagai berikut :

\begin{tabular}{|l|c|}
\hline Agriculture & 13 \\
\hline Mining & 22 \\
\hline Basic Industry and Chemicals & 49 \\
\hline Miscellaneous Industry & 38 \\
\hline Consumer Goods Industry & 29 \\
\hline $\begin{array}{l}\text { Infrastructure, Utilities } \\
\text { Transportation }\end{array}$ & 25 \\
\hline Trade, Services \& Investment & 77 \\
\hline
\end{tabular}

\subsection{Metode Analisis.}

Metode analisis yang digunakan dalam penelitian ini adalah metode analisis jalur.

3.3. Definisi Operasional dan Pengukuran Variabel.

Variabel-variabel penelitian yang digunakan adalah sebagai berikut :

- Jumlah utang jangka panjang (UJP), yang diukur dengan nilai Rupiah.

- Jumlah aset tetap (AT), yang diukur dengan yang diukur dengan nilai Rupiah.

- Jumlah penjualan (P), yang diukur dengan yang diukur dengan nilai Rupiah.

\subsection{Hipotesis dan Model.}

Hipotesis dan model dalam penelitian ini adalah sebagai berikut :

H1 : Utang jangka panjang (UJP) berpengaruh terhadap jumlah aset tetap (AT). 
H2 : Aset tetap (AT) berpengaruh terhadap jumlah penjualan (P).

\begin{tabular}{|l|l} 
Utang Jangka Panjang $\rightarrow$ Aset Tetap & Penjualan \\
\hline
\end{tabular}

\section{Hasil dan Pembahasan.}

Dengan menggunakan analisis jalur untuk pengujian hipotesis dalam penelitian ini, maka hasil yang diperoleh adalah bahwa aset tetap dari entitas-entitas bisnis yang menjadi sampel penelitian ini, kebanyakan disertai oleh pembiayaan dari utang jangka panjang, hal ini terlihat berdasarkan hasil pengujian yang menunjukkan adanya peningkatan aset tetap dari adanya peningkatan perolehan utang jangka panjang. Akan tetapi, seiring dengan terjadinya peningkatan aset tetap, maka tingkat penjualan dari entitas-entitas bisnis tersebut mengalami peningkatan, yang kemungkinan akan berdampak pada peningkatan laba, sekaligus untuk menutupi beban operasi (termasuk didalamnya penyusutan atas aset tetap tersebut), dan beban bunga pinjaman utang jangka panjang yang diperoleh. Hasil analisis dan persamaan yang diperoleh adalah sebagai berikut :

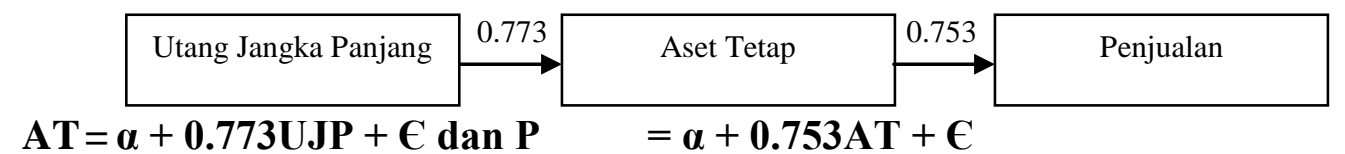

Hasil penelitian ini secara keseluruhan didukung oleh hasil penelitian dan pendapat dari Sadeghian, et. al. (2012), Khrawish \& Khraiwesh (2010), Alkhatib (2012), Iannariello, Morsy, Hagiwara (2007), Hovakimian, Hovakimian, \& Tehranian (2004), San \& Heng (2011), Aivazian, Ge, \& Qiu (2005).

\section{Kesimpulan.}

Berdasarkan hasil penelitian ini, maka dapat disimpulkan bahwa keputusan manajemen untuk memperoleh utang jangka panjang memiliki dampak atas tingkat penjualan, melalui pemanfaatan aset tetap secara optimal.

\section{Referensi.}

Adebayo, Alayemi Sunday. (2013). Relationship between assets utilization and corporate profitability: A case study of food and beverage industry quoted on the Nigerian stock exchange. Merit Research Journal of Business and Management Vol. 1(1) pp. 001-010, August, 2013. Copyright (C) 2013 Merit Research Journals.

Alkhatib. (2012). The Determinants of Leverage of Listed Companies. International Journal of Business and Social Science Vol. 3 No. 24 [Special Issue - December].

Aivazian, Varouj A., Ge, Ying, \& Qiu, Jiaping. (2005). Debt Maturity Structure and Firm investment. Financial Management, Winter 2005, pg $107-119$.

Chang, Shen-Ho, et. al. (2013). The Relationship between Organization Strategy, FixedAssets Investment and Earnings Quality. Asian Journal of Finance \& Accounting, ISSN 1946-052X, 2013, Vol. 5, No. 1.

Chhapra, Imran Umer \& Asim, Muhammad. (2012). Determinants of Capital Structuring : An Empirical Study of Growth and Financing Behavior of Firms of Textile Sector in Pakistan. Journal of Management and Social Sciences Vol. 8, No. 2, 01-10.

Chinaemerem, Osuji Casmir \& Anthony, Odita. (2012). Impact of Capital Structure on the Financial Performance of Nigerian Firms. Arabian Journal of Business and Management Review (OMAN Chapter) Vol. 1, No.12; July.

Hovakimian, Armen, Hovakimian, Gayane \& Tehranian, Hassan. (2004). Determinants of Target Capital Structure : The case of Dual Debt and Equity Issues. Journal of Financial Economics 71 (2004) 517-540. 
Iannariello, Maria Pia, Morsy, Hanan \& Hagiwara, Akiko Terada. (2007). Role of Debt Maturity on Firms' Fixed Assets during Sudden Stop Episodes : Evidence from Thailand. Journal of Applied Economics. Vol X, No. 2 (Nov 2007), 309-335.

Khrawish, Husni Ali \& Khraiwesh, Ali Husni Ali. (2010). The Determinants of the Capital Structure : Evidence from Jordanian Industrial Companies. JKAU: Econ. \& Adm., Vol. 24 No. 1, pp: 173-196 (2010 A.D./1431 A.H.).

Mahmud, Muhammad. (2003). The Relationship between Economic Growth and Capital Structure of Listed Companies : Evidence of Japan, Malaysia, and Pakistan. The Pakistan Development Review $42: 4$ Part II (Winter 2003) pp. 727-750.

Mohamad, Nor Edi Azhar Bte \& Abdullah, Fatihah Norazami Bt. (2012). Reviewing Relationship between Capital Structure and Firm's Performance in Malaysia. International Journal of Advances in Management and Economics, July.-Aug. 2012 | Vol.1 | Issue 4|151- 156.

Okwo, Ifeoma Mary, Ugwunta David Okelue, \& Nweze, Austin Uche. (2012). Investment in Fixed Assets and Firm Profitability : Evidence from the Nigerian Brewery Industry. European Journal of Business and Management, ISSN 2222-1905 (Paper) ISSN 2222-2839 (Online) Vol 4, No.20.

Sadeghian, Nima Sepehr, et. al. (2012). Debt Policy and Corporate Performance : Empirical Evidence from Tehran Stock Exchange Companies. International Journal of Economics and Finance; Vol. 4, No. 11; ISSN 1916-971X E-ISSN 1916-9728, Published by Canadian Center of Science and Education.

San, Ong Tze \& Heng, Teh Boon. (2011). Capital Structure and Corporate Performance of Malaysian Construction Sector. International Journal of Humanities and Social Science Vol. 1 No. 2; February.

Shubita, Mohammad Fawzi \& Alsawalhah, Jaafer Maroof. (2012). The Relationship between Capital Structure and Profitability. International Journal of Business and Social Science Vol. 3 No. 16 [Special Issue - August 2012].

\section{Lampiran}

Coefficients

\begin{tabular}{|c|c|c|c|c|c|c|}
\hline \multirow{2}{*}{\multicolumn{2}{|c|}{ Model }} & \multicolumn{2}{|c|}{$\begin{array}{c}\text { Unstandardized } \\
\text { Coefficients }\end{array}$} & \multirow{2}{*}{$\begin{array}{c}\text { Standardized } \\
\text { Coefficients }\end{array}$} & \multirow[b]{2}{*}{$t$} & \multirow[b]{2}{*}{ Sig. } \\
\hline & & B & Std. Error & & & \\
\hline & (Cons tant) & 3.309 & .278 & & 11.922 & .000 \\
\hline & UtangJPanjang & .780 & .023 & .773 & 33.512 & .000 \\
\hline
\end{tabular}

a. Dependent Variable: As etTetap

Coefficients

\begin{tabular}{|c|c|c|c|c|c|c|}
\hline \multirow{2}{*}{\multicolumn{2}{|c|}{ Model }} & \multicolumn{2}{|c|}{$\begin{array}{c}\text { Unstandardized } \\
\text { Coefficients }\end{array}$} & \multirow{2}{*}{$\begin{array}{c}\begin{array}{c}\text { Standardized } \\
\text { Coefficients }\end{array} \\
\text { Beta }\end{array}$} & \multirow[b]{2}{*}{$\mathrm{t}$} & \multirow[b]{2}{*}{ Sig. } \\
\hline & & B & Std. Error & & & \\
\hline & (Cons tant) & 5.555 & .261 & & 21.289 & .000 \\
\hline & AsetTetap & .649 & .021 & .753 & 31.462 & .000 \\
\hline
\end{tabular}

a. Dependent Variable: Penjualan 